\title{
Chloride concentrations in Lake Tanganyika: an indicator of the hydrological budget?
}

\author{
Philippe Branchu' and Laurent Bergonzini² \\ ${ }^{1}$ GEOTOP-UQAM-McGill, CP 8888, suc. Centre-Ville, Montréal (Québec) H3C 3P8, Canada \\ ${ }^{2}$ UMR-CNRS IDES, Bât. 504, Université Paris-Sud, 91405 ORSAY Cedex, France \\ E-mail of corresponding author: pons.branchu@wanadoo.fr
}

\begin{abstract}
On a historical time scale, this paper investigates the effect of hydroclimatic variations on the surface water salinity of Lake Tanganyika, the largest African lake and an open freshwater reservoir. Through annual water and chemical budgets, based on original and bibliographic data, a tracer of the water regime is proposed. Chloride, an inert and conservative element, seems to be the best candidate although its contribution to salinity is small; its use as a tracer of the water regime is validated on seasonal and historical time scales. Seasonally, a monthly water and chloride budget, constructed for an average year has been compared with data acquired in 1973. On a historical time scale, bibliographic data of surface chloride concentrations, compiled since 1939 have been compared with the level variation curve. The relation between lake level and surface water chloride concentration is significant on both time scales. Hence, the surface salinity/chlorinity of this freshwater lake is sensitive to hydroclimatic variations even if level variations are very limited in comparison with its great depth. This sensitivity is due mainly to the permanent thermo-haline stratification of the lake.
\end{abstract}

Keywords: climate, water budget, hydrochemical budget, Lake Tanganyika, limnology, salinity

\section{Introduction}

Lake Tanganyika, with a maximal depth of $1470 \mathrm{~m}$, is the deepest lake in Africa and the second deepest in the world. It extends over $600 \mathrm{~km}$ in the East African Rift, along $30^{\circ}$ East with an average width of $50 \mathrm{~km}$ and from $3^{\circ} 20^{\prime}$ to $8^{\circ} 50^{\prime}$ South (Fig. 1). Its catchment comprises numerous river basins, the largest being, in the north, the Ruzizi (the outflow of Lake Kivu), the Malagarasi in the East and the Lufubu in the South. The Lukuga River, the outflow from Lake Tanganyika, is a tributary of the Congo-Zaire. The climate is tropical with a long dry season from June to October, a short dry season in December-January and rainy seasons during the rest of the year. This climatic regime is influenced mainly by the position of the Inter-Tropical Convergence Zone (ITCZ). Lake Tanganyika is meromictic and oligotrophic and is characterised by a permanent thermohaline stratification (Coulter and Spigel, 1991); this limits mixing of lake water as well as penetration of oxygen into the first $150 \mathrm{~m}$ of the water column. The low salinity, $0.58 \mathrm{PSU}$, is influenced by the input of the Ruzizi (Hecky, 1978; Branchu, 2001).
Recent studies have improved knowledge of the system. On short time scales (such as the last century) (O'Reilly et al., 2003; Verburg et al., 2003) or long time scales (historical, climatic cycle) (Alin and Cohen, 2003), relationships between hydro-climatic variables and several bioecological and geophysicochemical features of the lake water and sediments have been investigated. Lakes are dynamic systems sensitive to local climatic variables such as precipitation, temperature, solar radiation and wind speed as well as to changes in catchment land use and tectonic activity. Hydrochemically, endoreic basin lakes, well represented in the oriental branch of the East African Rift (Fig.1), react to changes in the ratio between precipitation and evaporation by changes in depth and salinity (StreetPerrott and Harrison, 1985; Mason et al., 1994; Vance and Wolfe, 1996). Some indicators, such as diatoms, ostracodes and stable isotopes record this chemical variation and can be used in sedimentary archives as proxy-data for paleolimnological and paleoclimatological reconstructions via transfer functions (Gasse et al., 1995; Cohen et al., 1997; Verschuren et al., 2000; Barker et al., 2002; Grosjean et al., 
Regional Watersheds:

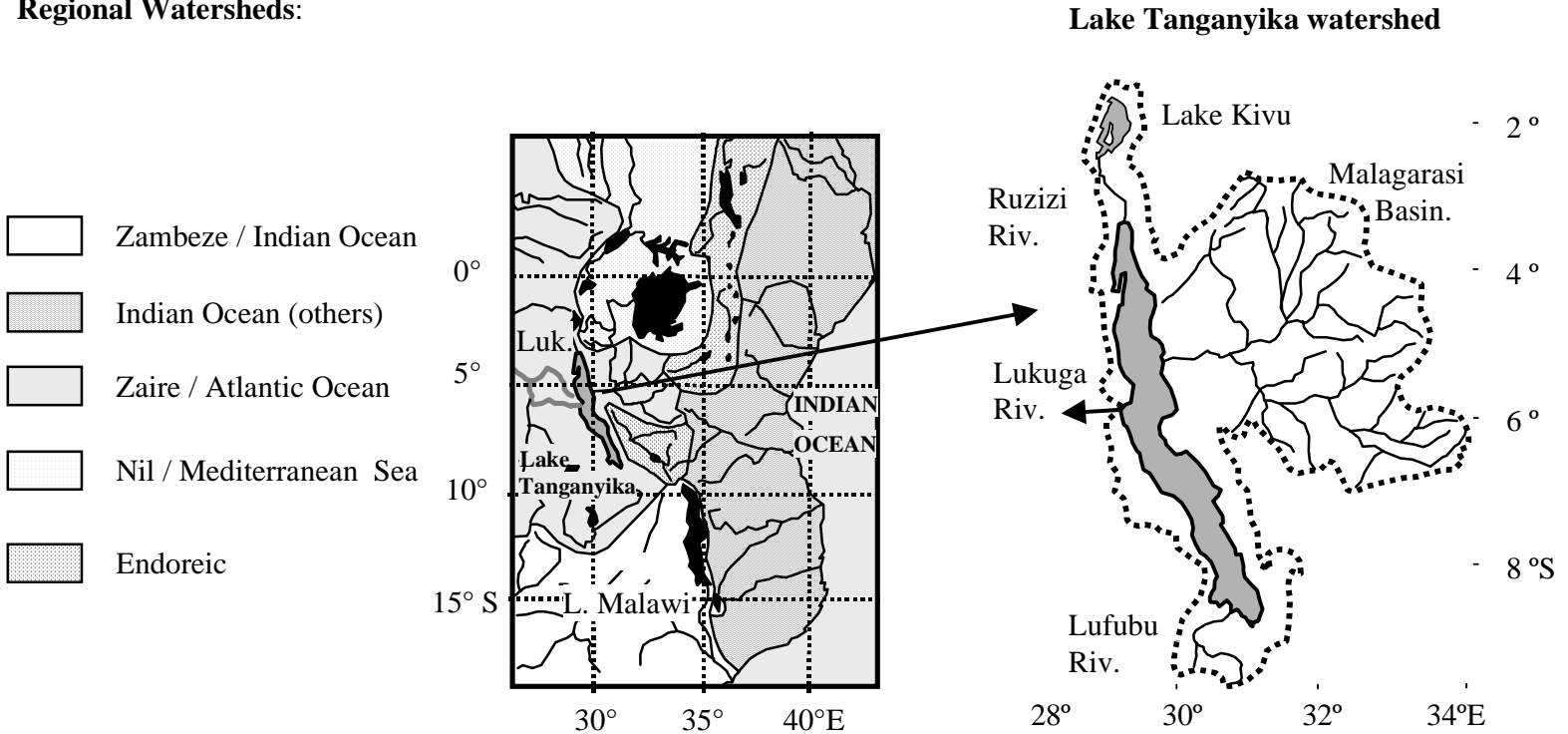

Fig. 1. Main lakes (black filled) and catchments of the East African rift.

2003). However, hydrothermal inputs, water/saline rock interactions and inputs contaminated by humans have also to be taken into account.

In large open lakes, like Tanganyika, salinity, which is often assumed to be constant, is of paleolimnological interest only during periods when the basin was closed, such as at the end of the $19^{\text {th }}$ century for Lake Tanganyika (Edmond et al., 1993) or/and during interruption of specific sources such as the Ruzizi, Lake Kivu's outlet to Lake Tanganyika (Hecky, 1978; Stoffers and Hecky, 1978). In these lakes, paleoclimatic reconstructions use non-chemical indicators such as stromatolithes (Cohen et al., 1997), ostracodes (Alin and Cohen, 2003) and diatoms (Johnson et al., 2002) as well as geochemical indicators such as stable isotopes (Cohen et al., 1997). The main objective of this article is to determine the effects of non-exceptional hydroclimatic variations on the physical chemistry (salinity) of the surface water in Lake Tanganyika. Hence, the hydrology and hydrochemistry of Lake Tanganyika are presented and the sensitivity of the salinity to hydroclimatic variations is investigated on annual and historical time scales.

\section{Hydrology}

\section{LAKE LEVEL FLUCTUATIONS}

The construction of a lake level curve (Fig. 2) from the end of the 19th century is based on historical measurements (Van Meel, 1987) and records of monthly lake levels (Bergonzini, 1998). The curve is characterised by seasonal fluctuations in amplitude of up to $70 \mathrm{~cm}$ and by inter-annual variations of more than a metre, caused by changes in the precipitation regime (Bergonzini, 1998; Nicholson, 1999). Changes in the outflow morphology are also responsible for other individual but permanent variations (Devroey, 1938; Charlier, 1955; Bergonzini, 1998).

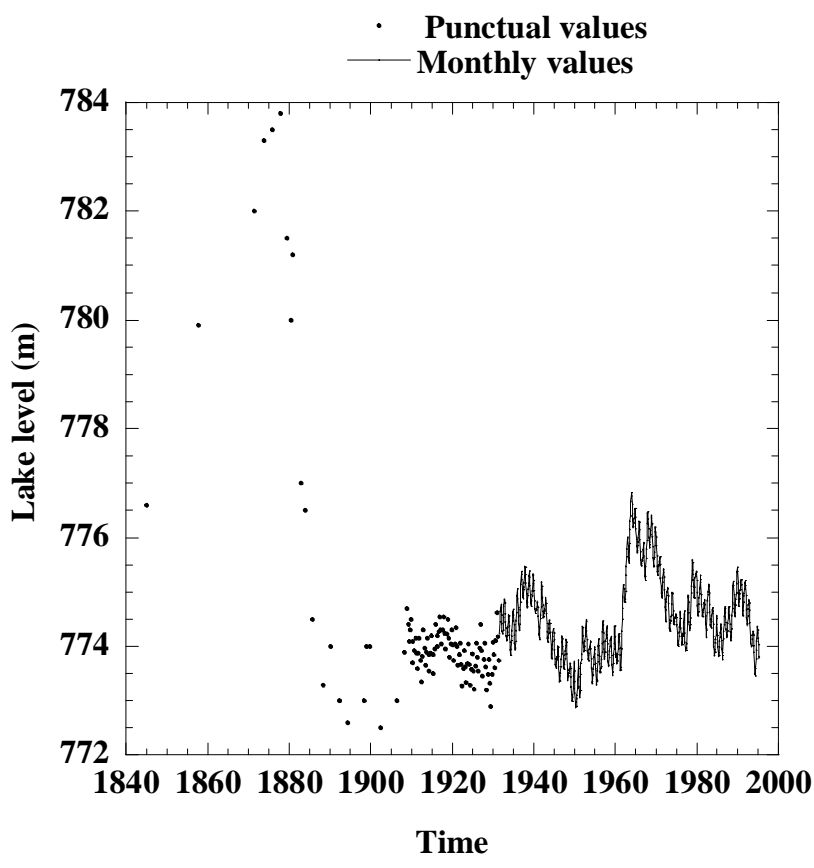

Fig. 2. Level variations of Lake Tanganyika from 1845 to 1995 (from Bergonzini, 1998) 


\section{HYDROLOGICAL BUDGE'T}

From monthly data over several years, the annual hydrological budget (Table 1) has been compiled using lake levels, tributary and outlet flow, evaporation and precipitation onto the lake surface (Bergonzini, 1998). The mean annual rainfall at the lake surface is $1090 \mathrm{~mm} \mathrm{year}^{-1}$ but more than $2000 \mathrm{~mm}_{\text {year }}^{-1}$ falls on the mountainous parts of the catchment (Bergonzini, 2002). The annual lake surface evaporation is about $1695 \mathrm{~mm}$ year $^{-1}$ (Bultot, 1993).

Table 1. Annual hydrological budget of Lake Tanganyika (adapted from Bergonzini, 1998 and 2002).

\begin{tabular}{|c|c|}
\hline Precipitations $\left(\mathrm{km}^{3} \text { year }{ }^{-1}\right)^{\prime}$ & 35.5 \\
\hline Tributaries $\left(\mathrm{km}^{3}\right.$ year $\left.{ }^{-1}\right)$ & 29.5 \\
\hline Evaporation $\left(\mathrm{km}^{3} \text { year-1 }\right)^{\prime}$ & 55.3 \\
\hline Outlet $\left(\mathrm{km}^{3}\right.$ year $\left.^{-1}\right)$ & 9.7 \\
\hline epi-metalimnetic exchange time (year) & 11 \\
\hline Residence time* (year) Lake & 290 \\
\hline Epilimnion & 7 \\
\hline Flushing time ${ }^{\sharp}$ (year) & 1946 \\
\hline Emptying time ${ }^{\#}$ (year) & 640 \\
\hline \multicolumn{2}{|c|}{$\begin{array}{l}\text { *Lake volume }=18880 \mathrm{~km}^{3}(\mathrm{Hecky} \text { and Degens, 1973), estimate of } \\
\text { Epilimnion volume }=2975 \mathrm{~km}^{3} . \\
\text { " For computations inputs correspond only to tributaries and losses to } \\
\text { outflow. } \\
\text { " Computed for the lacustrine surface }: 32600 \mathrm{~km}^{2}\end{array}$} \\
\hline
\end{tabular}

Inputs to the lake are equally distributed between rainfall and catchment runoff and outputs are controlled mainly by evaporation ( $85 \%$ of total losses).

The thermohaline stratification in the lake gives rise to three compartments in the water column: the epilimnion $(0$ $100 \mathrm{~m}$ ), the metalimnion (100-250 $\mathrm{m}$ ) and the hypolimnion $(>250 \mathrm{~m})$. The internal vertical water fluxes between these compartments, used to estimate epilimnetic residence time and epi-metalimnetic exchange time, are computed to explain the annual silicon mass budget, assuming (i) a primary production of $1000 \mathrm{mg} \mathrm{C} \mathrm{cm}^{-2} \mathrm{day}^{-1}$ (Hecky et al., 1991), (ii) a diatom/total phytoplankton ratio of 17\% (Hecky et al., 1978), (iii) a diatom Si:C mass ratio of 2.3:1 (Bootsma et al., 2003) and (iv) Si dissolution rates equivalent to those calculated for Lake Malawi (79\%, 14\% and 6\% of Si fixed during photosynthesis is dissolved in the epi-, meta- and hypolimnion respectively) based on a theoretical annual $\mathrm{Si}$ cycle (Fig. 3) that matches that characterised by Bootsma et al. (2003) relatively well. Moreover, the epilimnetic dissolution rate is similar to that estimated by Nelson et al. (1995) for the ocean where $60 \%$ of Si fixed in the euphotic zone is dissolved in the first $100 \mathrm{~m}$ of the water column. In these tropical lakes, the relatively high water temperature $\left(>22.5^{\circ} \mathrm{C}\right)$ contributes to this dissolution. Nevertheless, due to this methodology, the internal water fluxes computed for Lake Tanganyika are purely speculative.

The lake residence time, 290 years (Table 1) is about 1.5 times lower than residence times published previously (Meybeck, 1985; Bootsma and Hecky, 1993). The very long flushing time and the long emptying time stress the importance of precipitation and evaporation in the budget.

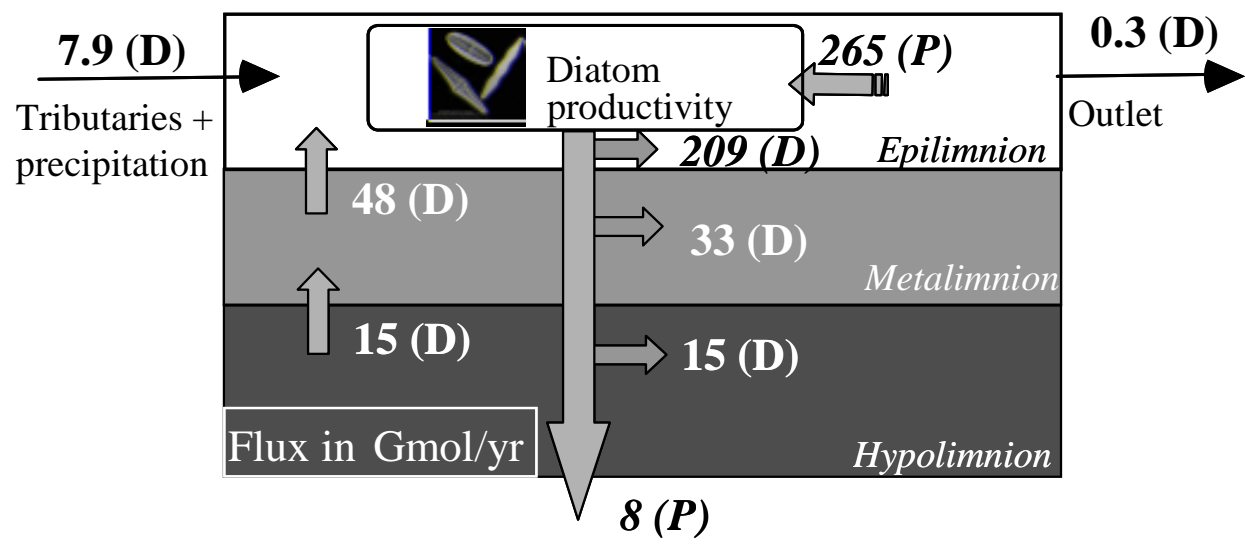

$(D)=$ dissolved flux, $(P)=$ particulate flux

(The particulate fluxes are computed in order to reach equilibrium in the cycle. The surface water productivity (from Bootsma et al., 2003) controls the epilimnetic dissolution and the flux to the sediments. Internal Si fluxes (epi-metalimnion and hypo-metalimnion) are computed from Vollmer et al. (2002) hydric fluxes (value without CFC-12 anoxic degradation) and Bootsma and Hecky (1993) and Branchu (2001) concentrations. Dissolved Si concentration in precipitation is from Bootsma et al. (2003). Other fluxes are adapted from Bergonzini (1998) and Branchu (2001).

Fig. 3. Annual cycle of silicon in Lake Malawi. 
The long residence time indicates a buffering of the lake against hydro-climatic changes on the secular time scale. Because of the permanent stratification, the epilimnetic stability is about 7 years and the epi-metalimnetic exchange time, about 11 years, is four times longer than that computed for Lake Malawi (Vollmer et al., 2002), a large stratified lake nearby (Fig. 1).

Lake level variations react at a historic time scale to the variability in the hydrological budget. At longer time scales (Little Ice Age, Last Glacial Maximum), variations in levels up to several hundred metres are suspected (Scholz and Rosendahl, 1988; Gasse et al., 1989; Alin and Cohen, 2003). For these past periods, specific hydrological indicators are necessary to reconstruct the paleolimnology.

\section{HYDROCHEMICAL BUDGET AND WATER REGIME INDICATOR}

The salinity of the lake water is linked to the ionic concentrations in solution. To determine the salinity and the contribution of the major ions to this quantity, a chemical characterisation of lake waters has been made in the framework of the CASIMIR (Comparative Analysis of Sedimentary Infill Mechanisms In Rifts) project. Six water columns (maximum depth: $187 \mathrm{~m}$ ) were sampled and two conductivity-temperature casts (using a CTD SBE 25 probe from Sea-Bird electronics) were made in the northern basin of the lake in August-September 1992. The samples were filtered in the laboratory through $0.45 \mu \mathrm{m}$ cellulose acetate syringe filters and, except for those to be used for anion analyses, acidified at $\mathrm{pH} \sim 1$ (using $\mathrm{HNO}_{3}$ suprapur); thereafter all were refrigerated in pre-washed polypropylene flasks until analysed. Cation $\left(\mathrm{Na}^{+}, \mathrm{K}^{+}, \mathrm{Ca}^{2+}, \mathrm{Mg}^{2+}\right)$ and anion $\left(\mathrm{Cl}^{-}, \mathrm{F}^{-}, \mathrm{HPO}_{4}{ }^{2-}, \mathrm{NO}_{3}{ }^{-}, \mathrm{SO}_{4}{ }^{2-}\right)$ concentrations were measured by capillary electrophoresis in acidified and unacidified subsamples, respectively. Si was determined by inductively coupled plasma atomic emission spectroscopy (ICP-AES). Alkalinity was measured in the laboratory by potentiometric titration. Chemical analyses were performed at the CEREGE (Centre Européen de Recherche et d'Enseignement en Géosciences de l'Environnement) in France.

The lake salinity and the contribution of the major ions are presented in Table 2. Lake conductivity was measured in situ (CTD) and also computed from ionic surface water concentrations using the equations of Hamilton (in Eaton et al., 1995). The surface water salinity, about $0.58 \%$, matches previous determinations (Millero, 2000). Computed and measured mean surface water conductivities are in good agreement (Table 2) and are consistent with published measurements (Plisnier et al., 1999). Main ionic contributors are, in decreasing order of magnitude, $\mathrm{CO}_{3}{ }^{2-}+\mathrm{HCO}_{3}{ }^{-}(66 \%)$, $\mathrm{Mg}^{2+}(11 \%), \mathrm{Na}^{+}(11 \%), \mathrm{K}^{+}(6 \%), \mathrm{Cl}^{-}(4 \%)$ and $\mathrm{Ca}^{2+}(1 \%)$. Salinity, through ion distribution, is controlled by several biogeophysical and chemical reactions. To identify the salinity components the most sensitive to the water regime, an annual hydrochemical budget has been determined, using

Table 2. Major ion mean concentration $\left(\mathrm{mmol} \mathrm{L}^{-1}\right)$ and contribution to the salinity $(\%)$ and computed and in situ measured (CTD) conductivity $(\mu \mathrm{S} / \mathrm{cm})$ in Lake Tanganyika surface $(0-70 \mathrm{~m})$ waters.

\begin{tabular}{|c|c|c|c|c|}
\hline & $\begin{array}{l}\text { Concentration }^{l} \\
\left(\text { mmolL }^{-1}\right)\end{array}$ & $\begin{array}{l}\text { Salinity }(\%) \\
\text { / contribution to } S_{T}(\%)\end{array}$ & $\begin{array}{l}\text { Conductivity }(\mu \mathrm{S} / \mathrm{cm} \\
\text { Measured }(C T D)^{3}\end{array}$ & Computed $^{4}$ \\
\hline $\mathrm{Na}^{+}$ & 2.638 & $0.061 / 10.5$ & & \\
\hline $\mathrm{K}^{+}$ & 0.842 & $0.034 / 5.9$ & & \\
\hline $\mathrm{Ca}^{2+}$ & 0.273 & $0.007 / 1.1$ & & \\
\hline $\mathrm{Mg}^{2+}$ & 1.611 & $0.063 / 10.9$ & & \\
\hline $\mathrm{Cl}^{-}$ & 0.707 & $0.025 / 4.3$ & & \\
\hline $\mathrm{F}^{-}$ & 0.044 & $0.001 / 0.1$ & & \\
\hline $\mathrm{HCO}_{3}^{-}$ & 6 & $0.366 / 63.5$ & & \\
\hline $\mathrm{CO}_{3}^{2-}$ & 0.28 & $0.017 / 2.9$ & & \\
\hline $\mathrm{SO}_{4}^{2-}$ & 0.036 & $0.003 / 0.6$ & & \\
\hline $\mathrm{HPO}_{4}^{2-}$ & 0.007 & $0.0004 / 0.1$ & & \\
\hline $\mathrm{S}_{\mathrm{T}}$ & & 0.577 & 665 & 650 \\
\hline \multicolumn{5}{|c|}{$\begin{array}{l}{ }^{1} \text { Mean value calculated from } 34 \text { samples of Bujumbura and Kigoma sub-basins } \\
{ }^{2} \text { The salinity is defined as the grams of inorganic salts in a kilogram of solution. For the computation, the density of } \\
\text { lake surface water is assumed to be equal to } 1 \text {. } \\
{ }^{3} \text { Mean value calculated from } 2 \text { CTD casts realised in Kigoma and Kalemie sub-basins }\end{array}$} \\
\hline \multicolumn{5}{|c|}{${ }^{4}$ Computed from ion concentrations using Hamilton's equation (in Eaton et al., 1995) } \\
\hline
\end{tabular}


Table 3. Annual hydrochemical budget of dissolved sodium, potassium, calcium, magnesium, chloride and silicon in Lake Tanganyika.

\begin{tabular}{llllllll}
\hline & $N a$ & $K$ & $C a$ & $M g$ & $C l$ & $\mathrm{Si}$ \\
\hline Reservoir & Lake & 53314.4 & 16826.9 & 5658.9 & 32128.6 & 14673.1 & 3563.5 \\
$(\mathrm{Gmol})$ & Epilimnion & 8558.6 & 2708.6 & 844.6 & 5227.6 & 2382.2 & 53.7 \\
Flux & Tributaries & 33.59 & 7.99 & 7.44 & 17.8 & 7.89 & 4.54 \\
$\left(\mathrm{G} \mathrm{mol} \mathrm{yr} \mathrm{r}^{-1}\right)$ & Precipitation & 0.53 & 0.15 & 0.26 & 0.08 & 0.33 & 1.3 \\
& Outflow & 28.7 & 8.56 & 2.42 & 17.9 & 8.48 & 0.21 \\
& Meta to Epilimnion & 57.6 & 12.2 & 5.9 & 17.8 & 8.7 & 29.2 \\
$\mathrm{t}_{\mathrm{i}}(\%)$ & & & & & & \\
$\tau_{\mathrm{i}}($ year $)$ & Lake & 16 & -5 & 69 & 2 & -3 & 96 \\
& Lake & 1562 & 2069 & 735 & 1797 & 1784 & 611 \\
& Epilimnion & 9.0 & 9.0 & 9.0 & 9.0 & 9.0 & 0.3 \\
\hline
\end{tabular}

(due to lack of data availability) only $\mathrm{Na}, \mathrm{K}, \mathrm{Ca}, \mathrm{Mg}, \mathrm{Cl}$ and Si. Silicon, the behaviour of which is known in a large tropical large lake (Hecky et al., 1991; Bootsma et al., 2003) is used as a control.

The chemical composition of the epilimnion is presented in Table 2. As the present data are restricted to a maximum water depth of $187 \mathrm{~m}$, they have been augmented by those of Craig (1974) and Van Meel (1987) for deep waters. From a comparison of these three data sets, a chemical steady state of the lake may be assumed at least for the first $187 \mathrm{~m}$ of the water column. The chemistry of the tributaries has been established from the literature (Beauchamp, 1939; Dubois, 1958; Talling and Talling, 1965; Symoens, 1968; Degens et al., 1971; Kilham and Hecky, 1973; Craig, 1974; Meybeck, 1985; Gourdin et al., 1986; Caljon, 1987; Cohen and Thouin, 1987; Van Meel, 1987; Casanova and Thouin, 1990; Pflumio et al., 1994; Kimbadi et al., 1999; Vandelannoote et al.,1999). Incoherent data and data not satisfying solution electro-neutrality were discarded. (i.e. if [ $\Sigma$ cations $-\Sigma$ anions $] /[\Sigma$ cations $+\Sigma$ anions $]>0.3$; with $\Sigma$ cations and $\Sigma$ anions in meq $1^{-1}$ ). Unfortunately, the rivers which satisfy this criterion are mainly in the north of the catchment. Hence, a methodology has been developed to associate a chemical flux with a hydrological flux by dividing the basin into four areas (north-east, north-west, south-west and south-east) and determining, for each, the river's mean chemical composition. Due to its specific composition, the Ruzizi river has not been integrated into this computation. These four rivers are then weighted by their annual flow and a mean chemical composition is calculated and extrapolated to the chemically unknown parts of the basin. Temporal variation in the chemistry of the tributaries has not been incorporated because of uncertainties in their sampling dates. However, the importance of chemical and flow variability has been demonstrated by
Craig (1974), Gourdin et al. (1986) and Vandelannoote et al. (1999). The chemical composition of rainfall is the average of some East African data (Rodhe et al., 1981; Bootsma et al., 1996; Bootsma et al., 2003). The watersediment interface and lake-groundwater fluxes are not considered. Sub-lacustrine hydrothermal springs occur in the lake (Pflumio et al., 1994) but their influence on lake chemistry is low and has been neglected.

The chemical fluxes and stocks constituting the system are presented in Table 3. The main source of elements to the lake is catchment runoff ( $>96 \%$, for $\mathrm{Ca}, \mathrm{Na}, \mathrm{Mg}, \mathrm{Cl}$, and $\mathrm{K}$ and ca $78 \%$ for $\mathrm{Si}$ ). If the epilimnion alone is considered, the vertical meta-epilimnetic flux has to be integrated. This flux (or 'internal recharge', according to Van Meel, 1987) is the dominant source of Si and is roughly equal to the input of other elements by the tributaries.

The hydrochemical budget is characterised for each chemical element ' $i$ ' by two main variables. The first is the retention rate $\left(\mathrm{t}_{\mathrm{i}}=\left[\left(\mathrm{M}_{\mathrm{a}, \mathrm{i}}-\mathrm{M}_{\mathrm{p}, \mathrm{i}}\right) / \mathrm{M}_{\mathrm{a}, \mathrm{i}}\right] \times 100\right.$ (in \%), with the yearly molar amount $\left(\right.$ mol year $\left.^{-1}\right)$ of inputs $\left(\mathrm{M}_{\mathrm{a}, \mathrm{i}}\right)$ and outputs $\left(\mathrm{M}_{\mathrm{p}, \mathrm{i}}\right)$; this characterises the reactivity of element $i$ in the water column. Positive and negative retention rates correspond respectively to removal from and release to the water column by biological, physical and chemical processes. A rate corresponding to zero indicates a nonreactive element. The second variable, the residence time (in years) of element $\mathrm{i}\left(\tau_{\mathrm{i}}=\mathrm{M}_{\mathrm{R}, \mathrm{i}} /\left(\mathrm{M}_{\mathrm{a}, \mathrm{i}}\right)\right.$, with $\mathrm{M}_{\mathrm{R}, \mathrm{i}}$ the molar quantity in the reservoir being considered) describes the temporal sensitivity of the system to changes in flux and the efficiency of recycling of that element.

The retention rates and residence times are computed for the lake and its epilimnion (Table 3). Si, considered as a nutrient due to its involvement in the biological cycle of diatoms, is the most reactive $\left(\mathrm{t}_{\mathrm{Si}}=96 \%\right)$ and, with the shortest residence times (Table 3 ), is the most rapidly recycled 
element. Ca, characterised by a high reactivity $\left(\mathrm{t}_{\mathrm{Ca}}=69 \%\right)$ and a short residence time, may be linked to precipitation of magnesian calcium carbonates in surface waters that is suspected from thermodynamic computations (Cohen et al., 1997; Branchu, 2001). However, the reactivity and residence time of magnesium do not illustrate this process (Table 3 ). $\mathrm{Na}$ is characterised by a long residence time and an intermediate retention rate $\left(\mathrm{t}_{\mathrm{Na}}=16 \%\right) . \mathrm{Cl}$ and $\mathrm{K}$ are characterised by very low retention rates and long residence times. The $\mathrm{Cl}$ and $\mathrm{K}$ concentrations are well buffered in regard to flux changes. As $\mathrm{K}, \mathrm{Na}$ and $\mathrm{Mg}$ are potentially involved in clay mineral weathering and formation (Gieskes and Lawrence, 1976; Perry et al., 1976; Yuretich and Cerling, 1983; Hecky and Bugenyi, 1992; Cerling, 1996) they cannot be considered as inert elements in the lake; moreover this could explain the intermediate $\mathrm{Na}$ retention rate and the global non-reactivity of $\mathrm{Mg}$. The residence times at depth are longer, reflecting the isolation and inertia of deep waters. All the elements, except $\mathrm{Si}$, have an epilimnetic residence time of about 9 years that is close to that of the water (Tables 1 and 3).

In hydrological studies, the ideal tracer should be highly soluble, conservative, non-reactive and, with identifiable sources, $\mathrm{Cl}$ seems to be the best candidate in Lake Tanganyika, even if it contributes only $4 \%$ to salinity. Chloride's characteristics shown here are often considered as basic assumptions leading to its use as a hydrological tracer (e.g. Ojiambo and Lyons, 1996). Chloride is useful in different situations; in semi-arid to arid soils it facilitates evaluation of water fluxes (Scanlon, 2000) while, in aquifers, it helps to evaluate recharge and the regional climatic evolution (Allison and Hughes, 1978; MacFarlane et al., 2000).

One anion that contributes to salinity has not been considered, $\mathrm{HCO}_{3}^{-}\left(+\mathrm{CO}_{3}^{2-}\right)$. However, $\mathrm{HCO}_{3}^{-}$is not a suitable candidate in this lake due to its involvement in the biological and carbonate mineral cycles (Craig, 1974).

\section{Validation of tracer}

\section{SEASONAL TIME SCALE}

Annual monitoring of chloride concentrations should characterise the seasonal variability of lake levels (Fig. 2). A monthly chloride budget, for an average year, is proposed for the surface waters (Eqns. 1, 2 and 3).

$$
\begin{aligned}
& (\mathrm{Cl})_{\mathrm{j}}=\mathrm{M}_{\mathrm{j}} / \mathrm{V}_{\mathrm{j}} \\
& \mathrm{V}_{\mathrm{j}}=\mathrm{V}_{\mathrm{j}-1}+\mathrm{P}_{\mathrm{j}}+\mathrm{Q}_{\mathrm{aj}}-\mathrm{E}_{\mathrm{j}}-\mathrm{Q}_{\mathrm{ej}}
\end{aligned}
$$

$$
M_{j}=M_{j-1}+M_{P j}+M_{a j}-M_{e j}
$$

With for the month $\mathrm{j}$ :

- the chloride concentration $\left(\mathrm{mol} \mathrm{L}^{-1}\right)$ in water layer considered, $(\mathrm{Cl})_{\mathrm{i}}$.

$(\mathrm{Cl})_{0}=0.00075 \mathrm{~mol} \mathrm{~L}^{-1}$

- the volumes $(\mathrm{L})$ : of the water layer considered $\left(\mathrm{V}_{\mathrm{j}}\right)$, of the precipitation input $\left(\mathrm{P}_{\mathrm{j}}\right)$, of the tributary input $\left(\mathrm{Q}_{\mathrm{aj}}\right)$, of the evaporation loss $\left(E_{j}\right)$ and of the outlet loss $\left(Q_{e j}\right)$.

$\mathrm{V}_{0}=32600 . \mathrm{H}_{\text {wat }} \cdot 10^{9}$ where $\mathrm{H}_{\text {wat }}$ is the thickness of the surface layer considered $(\mathrm{m})$,

- the chloride amount (moles): in $\mathrm{V}_{\mathrm{j}}\left(\mathrm{M}_{\mathrm{j}}\right)$, in the precipitation input $\left(\mathrm{M}_{\mathrm{Pj}}\right)$ in the tributary input $\left(\mathrm{M}_{\mathrm{aj}}\right)$ and in the outlet loss $\left(\mathrm{M}_{\mathrm{ej}}\right)$.

It has been assumed that:

- the monthly chloride concentration in the tributaries is constant,

- the outflow concentration for the month $\mathrm{j}$ is equal to the surface concentration of month $\mathrm{j}-1$. The surface layer thickness is an input variable. Monthly water fluxes used in the budget (Table 4) are consistent with the yearly ones (Table 1). Chloride concentrations of Lake Tanganyika's surface waters are assumed to be spatially homogeneous (Van Meel, 1987; Branchu, 2001).

Fieldwork in the northern basin in 1973 (Craig, 1974) was used to validate the model and to optimise the surface

Table 4. Monthly data of precipitation, evaporation, tributary flow and outflow (expressed in $\mathrm{mm}$ relative to the lake surface, $32600 \mathrm{~km}^{2}$ ) for an average year (adapted from Bergonzini, 1998 and 2002).

\begin{tabular}{lllll}
\hline \multicolumn{5}{c}{${\text { Water flux }\left(\text { mmonth }^{-1}\right)}^{\text {Evaporation }}$} \\
Month & $\begin{array}{l}\text { Precipitation } \\
(P)\end{array}$ & $\begin{array}{l}\text { Tribury } \\
\text { inflow(Qi) }\end{array}$ & $\begin{array}{l}\text { Outlow } \\
(\text { Qo) }\end{array}$ \\
\hline Jan & 149 & 132 & 84 & 24 \\
Feb & 139 & 124 & 95 & 23 \\
Mar & 167 & 138 & 138 & 27 \\
Apr & 157 & 130 & 148 & 29 \\
May & 66 & 149 & 107 & 32 \\
Jun & 5 & 147 & 73 & 29 \\
Jul & 2 & 144 & 54 & 27 \\
Aug & 3 & 147 & 38 & 24 \\
Sept & 19 & 167 & 33 & 21 \\
Oct & 49 & 153 & 32 & 20 \\
Nov & 142 & 135 & 42 & 20 \\
Dec & 192 & 130 & 61 & 22 \\
TOTAL & 1090 & 1696 & 905 & 298 \\
\hline
\end{tabular}


layer thickness by comparing the computed values with actual measurements. Chloride concentrations are expressed in $\mathrm{mg} \mathrm{L}^{-1}$ hereafter.

Equation 1 presents the relation between chloride concentration and the volume of the water layer considered and, therefore, the lake level. Measured and computed high/ low levels are in agreement. However, the decrease in level measured during the dry season of 1973 is more pronounced; its highest amplitude $(0.8 \mathrm{~m})$ exceeded the yearly computed value. This lower level is linked to the flushing period, when rainfall was relatively low, after the excess of water in the 60s (Fig. 2). This decrease is concomitant with an increase in the outlet flow capacity (Bergonzini, 1998). There is good agreement between the measured and computed (with a surface layer $10 \mathrm{~m}$ thick) water levels for 1973 (Fig. 4a) and between measured and computed concentrations, even if concentrations were analysed mainly at the end of the dry season (Fig. 4b). This thickness is justified as the monthly variations of the hydrochemical budget are induced by changes in the input/evaporation ratio and the evaporation affects a shallow layer.

The difference between the maximal and minimal computed concentrations of chloride is about $5 \%$ around the mean annual concentration $\left(26.3 \mathrm{mg} \mathrm{L}^{-1}\right)$. This change, if other solute concentrations are unchanged, should lead to a salinity change of $0.001 \%$. Likewise, the variation between measured lake levels, about $0.8 \mathrm{~m}$, corresponds to about $0.1 \%$ of the mean lake depth $(580 \mathrm{~m})$.

The relationship between level and concentration demonstrates that surface concentration chloride is, at the seasonal scale, an appropriate hydrological budget indicator.

\section{INTERANNUAL TIME SCALE}

Fluctuations in lake levels since the $19^{\text {th }}$ century should also have induced changes in the surface chloride concentrations. Through a bibliographic review, 56 values of surface concentration have been found and compared with corresponding lake levels. Data not dated precisely (day, month) have been associated with the mean annual level. While, to avoid the influence of seasonal variations, only data measured below a depth of $10 \mathrm{~m}$ should have been selected, in the absence of information on actual sampling depths, all data from the 0-20 m layer have been used in the comparison.

Lake levels and surface chloride concentrations are correlated; when the level is high, the chloride concentration is low and vice versa. Devroey (1938) reported that, at the end of the $19^{\text {th }}$ century, a succession of exceptionally dry seasons reduced the lake level below its outlet and the resulting stagnation increased the salinity of the water and gave it an acrid taste. The statistical relationship between water level measurements and concentrations has a correlation coefficient of $56 \%$ which increases to $60 \%$ if the mean level for the three years prior to sampling is used in the correlation. (Fig. 5). Unfortunately, no concentration data have been found for the 1962-68 period when the lake level was at its highest (Fig. 2).

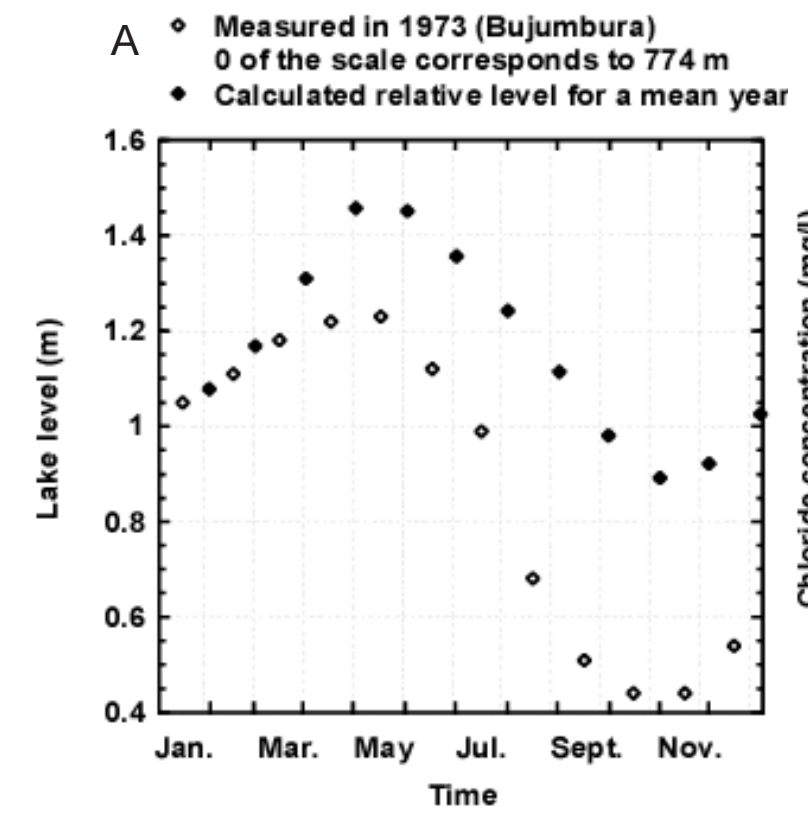

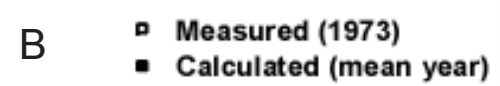

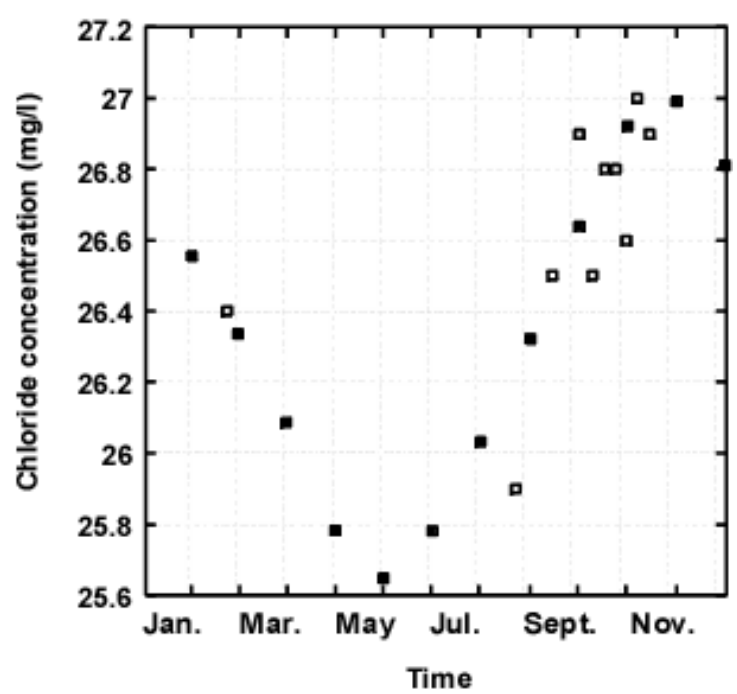

Fig. 4. Comparison between (A) relative levels computed for a mean year and measured in 1973 and (B) surface chloride concentrations computed (0-10 m) for an average year and measured in 1973 (Craig, 1974). 


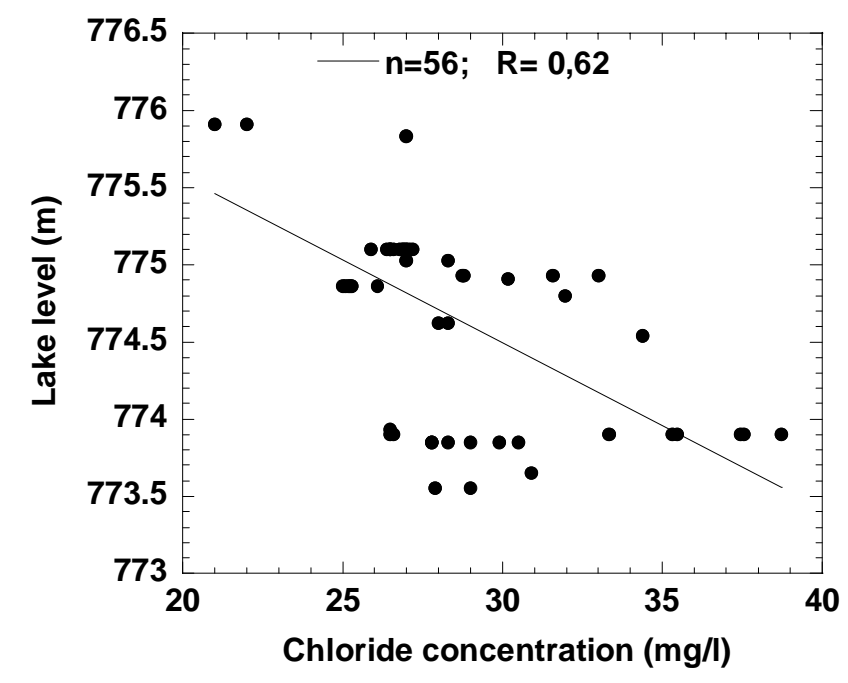

Fig. 5. Statistical relation, from 1939 to 1992, between level and surface water chloride concentration of Lake Tanganyika computed using the mean level for the three years before sampling.(Chloride concentrations from Ricardo (1939), Beauchamp (1940), Symoens (1968), Degens and Kulbicki (1973), Craig (1974), Meybeck (1985), Cohen and Thouin (1987), Van Meel (1987), Pflumio et al. (1994) and Branchu (2001)).

The difference between maximal and minimal concentrations over the present study period is $63 \%$ of the $28.23 \mathrm{mg} \mathrm{L}^{-1}$ average value. This change in concentration, if other solute concentrations remain unchanged, should induce a change of $0.018 \%$ in salinity. The change in lake level is about $2.4 \mathrm{~m}$, about $0.4 \%$ of the mean depth of the lake. A significant part of the variability in concentration may be linked to the analytical and sampling methodologies, errors in which are difficult to quantify. Seasonal monitoring of the chemistry of the lake is needed to validate the relationship between concentration and level.

While the variations in lake level, relative to lake depth, are limited, the sensitivity to hydro-climatic conditions of chloride concentrations in surface waters has been demonstrated.

\section{Conclusion}

The usual assumption that chloride is a suitable indicator of the water budget has been demonstrated for Lake Tanganyika by hydrochemical budget studies. In this large open freshwater lake, hydroclimatic changes induce variations in surface water salinity and chlorinity. This relationship, here shown on a seasonal time scale, should be investigated further at the inter-annual time scale by including more recent measurements. The changes in the water surface reflect the influence of evaporation and precipitation on the water budget and the relatively long epi-metalimnetic exchange time in relation to the permanent thermohaline stratification.

This relation between surface chlorinity and water budget should lead to new applications in high resolution paleoclimatical and paleolimnological reconstructions in Lake Tanganyika. Nevertheless, the existence of biological and/or physico-chemical indicators (proxy-data) sensitive enough to record such fast and low chlorinity variations is questioned.

\section{Acknowledgements}

The authors are grateful to Prof. Jean Klerkx for his confidence and to Dr Piet Verburg for his useful comments. The work was supported by the French GDR PROMESSE (Prof. Hamelin, Univ. Aix-Marseille III) and by the CNRS FU N ${ }^{\circ} 17$ (CEREGE). The Fieldwork was carried out in the framework of the Belgian project CASIMIR (Comparative Analysis of Sedimentary Infill Mechanisms in Rifts).

\section{References}

Alin, S.R. and Cohen, A.S., 2003. Lake-level history of Lake Tanganyika, East Africa, for the past 2500 years based on ostracode-inferred water-depth reconstruction. Palaeogeogr. Palaeoclimatol., 199, 31-49

Alison, G.B. and Hughes, M.W., 1978. The use of environmental chloride and tritium to estimate total recharge to an unconfined aquifer. Aust. J. Soil Res., 16, 181-195.

Barker, P., Telford, R., Gasse, F. and Thevenon, F., 2002. Late Pleistocene and Holocene palaeohydrology of Lake Rukwa, Tanzania, inferred from diatom analysis. Palaeogeogr. Palaeoclimatol., 187, 295-305.

Beauchamp, R.S.A., 1939. Hydrology of lake Tanganyika. Internationale Revue der Gesamten Hydrobiologie, 39, 316353.

Beauchamp, R.S.A., 1940. Chemistry and hydrography of Lakes Tanganyika and Nyasa. Nature, 146, 253-256.

Bergonzini, L., 1998. Bilans hydriques de lacs (Kivu, Tanganyika, Rukwa and Nyassa) du rift est-africain. Musée Royal de l'Afrique Centrale, Ann. Sci. Géol., 103, 1-183.

Bergonzini, L., 2002. Computed mean monthly water balance of a large lake: the case of lake Tanganyika. In: Lake Issikul: its natural Environment, J. Klerkx and B. Imanackunov (Eds.), . NATO publication Kluwer, Dordrecht, The Netherlands. 217244.

Bootsma, H.A. and Hecky, R.E., 1993. Conservation of the African Great Lakes: A limnological perspective. Conservation Biology, 7, 644-655.

Bootsma, H.A., Bootsma, M.J. and Hecky, R.E., 1996. The chemical composition of precipitation and its significance to the nutrient budget of Lake Malawi. In: Limnology, Climatology and Paleoclimatology of the East African Lakes, T. C. Johnson and E.O. Odada (Eds.). Gordon and Breach, Amsterdam, The Netherlands. 251-266.

Bootsma, H.A., Hecky, R.E., Johnson, T.C., Kling, H.J. and Mwita, A.J., 2003. Inputs, outputs and internal cycling of silica in a large, tropical lake. J. Great Lakes Res., 29, 121-138. 
Branchu, Ph., 2001. Cycle des éléments majeurs et traces dans les grands lacs de rift tropicaux (Lacs Tanganyika et Malawi). Processus et enregistrements biogéochimiques. Musée Royal de l'Afrique Centrale, Ann. Sci. Géol., 106., 374.

Bultot, F., 1993. Evaporation from a tropical lake: comparison of theory with direct measurements. J. Hydrol., 143, 513-519.

Caljon, A.G., 1987. A recently landlocked brackish-water lagoon of lake Tanganyika : physical and chemical characteristics, and spatio-temporal distribution of phytoplankton. Hydrobiologia, 153, 55-70.

Casanova, J. and Thouin, C., 1990. Biosédimentologie des carbonates microbiens du lac Tanganyika (Burundi). Implications hydrologiques. Bull. Soc. Géol. Fr., 6, 647-656.

Cerling, T.E., 1996. Pore Water chemistry of an Alkaline Lake: Lake Turkana, Kenya. In: Limnology, Climatology and Paleoclimatology of the East African Lakes, T. C. Johnson and E.O. Odada (Eds.). Gordon and Breach, Amsterdam, The Netherlands. 225-240.

Charlier, 1955. Etudes hydrodynamiques dans le bassin de Lualaba (Congo Belge) (1952-1954). Mémoire de l'Institut Royal des Sciences Coloniales (Belg.), Classe Sci. Technol. In-8 $8^{\circ}, \mathbf{1}, 75$.

Cohen, A. and Thouin, C., 1987. Nearshore carbonate deposits in Lake Tanganyika. Geology, 15, 414-418.

Cohen, A.S., Talbot, M.R., Awramik, S.M., Dettman, D.L. and Abell, P., 1997. Lake level and paleoenvironmental history of Lake Tanganyika, Africa, as inferred from late Holocene and modern stromatolites. Geol. Soc.Amer.Bull., 109, 444-460.

Coulter, G.W. and Spigel, R.H., 1991. Hydrodynamics. In: Lake Tanganyika and its Life, G.W. Coulter, (Ed.). Natural History Museum Publication and Oxford University Press, Oxford, UK. $49-75$.

Craig, H., 1974. Lake Tanganyika geochemical and hydrographic study: 1973 expedition. Technical Report, Woods Hole Oceanographic Institution, USA.

Degens, E.T. and Kulbicki, G., 1973. Hydrothermal origin of metals in some East African Rift Lakes. Miner. Depos., 8, 388-404.

Degens, E.T., Von Herzen, R.P. and Wong, H.K., 1971. Lake Tanganyika: water chemistry, sediments, geologic structure. Naturwissenschaften, 58, 229-240.

Devroey, E.J.,1939. Le problème de la Lukuga exutoire du lac Tanganyika. Mémoire de l'Institut Royal des Sciences Coloniales (Belg.), 1, 1-27.

Devroey, E.J., 1949. A propos de la stabilisation du niveau du lac Tanganyika et de l'amélioration de la navigabilité du fleuve Congo (Bief moyen du Lualaba, kindu -ponthierville). Mémoire de l'Institut Royal des Sciences Coloniales (Belg.) Sci. Technol., in- $8^{\circ}, \mathbf{5}, 135$.

Dubois, J-Th., 1958. Composition chimique des affluents du nord du lac Tanganyika. Académie Royale des Sciences Coloniales, Bulletin des Scéances (Belgique), IV, 1226-1237.

Eaton, A.D., Clesceri, L.S. and Greeberg, A.E., 1995. Standards methods for the examination of water and wastewater. American Public Health Association. Washington D.C.

Edmond, J.M., Stallard, R.F., Craig, H., Craig, V., Weiss, R.F. and Coulter, G.W., 1993. Nutrient chemistry of the water column of Lake Tanganyika. Limnol. Oceanogr. 3, 725-738.

Gasse, F., Ledee, V., Massault, M. and Fontes, J.C., 1989. Water level fluctuations of Lake Tanganyika in phase with oceanic changes during the last glaciation and deglaciation. Nature, 342, $57-59$.

Gasse, F., Juggins, S. and Khelifa, L.B., 1995. Diatom-based transfer functions for inferring past hydrochemical characteristics of African lakes. Paleogeogr. Paleolimnol., 117, $31-54$.
Gieskes, J.M. and Lawrence, J.R., 1976. Interstitial water studies, Leg 35. In Hollister, C.D., Craddock, C., et al., Init. Repts DSDP, 35, 407-426.

Gourdin, J., Hollebosch, P. and Kibiriti, C., 1986. Etude chimique des eaux de la Rusizi et de ses affluents au Burundi. Institut des Sciences Agronomiques du Burundi- Département de l'Aménagement du Milieu- Laboratoire de chimie agricole, Note technique.

Grosjean, M., Cartajena, I., Geyh, M.A. and Nunez, L.A., 2003. From proxy-data to paleoclimate interpretation: The midHolocene paradox of the Atacama Desert, northern Chile. Palaeogeogr. Palaeoclimatol., 194, 247-258.

Hecky, R.E., 1978. The Kivu-Tanganyika basin: the last 14,000 years. Polish Arch. Hydrobiol., 25, 159-165.

Hecky, R.E. and Bugenyi, F.W.B., 1992. Hydrology and chemistry of the African Great Lakes and water quality issues: Problems and solutions. Mitt. Int. Vereinigung theor. angew. Limnol., 23, $45-54$.

Hecky, R.E. and Degens, E.T., 1973. Late Pleistocene-Holocene chemical stratigraphy and paleolimnology of the rift valley lakes of central Africa. Woods Hole Oceanographic Institution, Technical Report, WHOI-73-28.

Hecky, R.E., Fee, E.J., Kling, H. and Rudd, J.W.M., 1978. Studies on the Planktonic Ecology of Lake Tanganyika. Western Region Fisheries and Marine Service, Department of Fisheries and the Environment, Winnipeg, Canada. pp51 http://www.ilec.or.jp/ database)

Hecky, R.E., Spigel, R.H. and Coulter, G.W., 1991. The nutrient regime. In: Lake Tanganyika and its Life, G.W. Coulter (Ed.), London, Natural History Museum Publications and Oxford University Press, Oxford, UK. 76-89.

Johnson, T. C., Brown, E.T., McManus, J., Barry, S., Barker, P. and Gasse, F., 2002. A high-resolution paleoclimate record spanning the past 25,000 years in southern East Africa. Science, 295, 113-132.

Kilham, P. and Hecky, R.E., 1973. Fluoride, Geochemical and ecological significance in East African waters and sediments. Limnol. Oceanogr., 18, 932-945.

Kimbadi, S., Vandelannoote, A., Deelstra, H., Mbemba, M. and Ollevier, F., 1999. Chemical composition of the small rivers of the north-western part of Lake Tanganyika. Hydrobiologia, 407, $75-80$.

MacFarlane, P.A., Clark, J.F., Davisson, M.L., Hudson, G.B. and Whittemore, D.O., 2000. Late-Quaternary Recharge Determined from Chloride in Shallow Groundwater in the Central Great Plains. Quaternary Res., 5, 167-174.

Mason, I.M., Guzkowska, M.A.J., Rapley, C.G. and Street-Perrott, F.A., 1994. The response of lake levels and areas to climate change. Climatic Change, 27, 161-197.

Meybeck, M., 1985. Evaluation préliminaire de la pollution du Lac Tanganyika. United Nations Educational, Scientific and Cultural Organisation Report, Paris, France.

Millero, F.J., 2000. The equation of State of Lakes. Aquat. Geochem., 6, 1-17.

Nelson, D.M., Treguer, P., Brzezinski, M.A., Leynaert, A. and Queguiner, B., 1995. Production and dissolution of biogenic silica in the ocean: revised global estimates, comparison with regional data and relationship with biogenic sedimentation. Global Biogeochem. Cycle., 9, 359-372.

Nicholson, S.E., 1999. Historical and modern fluctuations of lakes Tanganyika and Rukwa and their relationship to rainfall variability. Climatic Change, 41, 53-71. 
Ojiambo, B.S. and Lyons, W.B., 1996. Residence times of major ions in Lake Naivasha, Kenya, and their relationship to lake hydrology. In: Limnology, Climatology and Paleoclimatology of the East African Lakes, T.C. Johnson and E.O. Odada (Eds). Gordon and Breach, Amsterdam.,The Netherlands. 267-280.

O'Reilly, C.M., Alin, S.R., Plisnier, P.D., Cohen, A.S. and Mckee, B.A., 2003. Climate change decreases aquatic ecosystem productivity of Lake Tanganyika, Africa. Nature, 424, 766-768.

Perry, E.A., Gieskes, J.M. and Lawrence, J.R., 1976. Mg, Ca and O18/O16 exchange in the sediment-pore water system, Hole 149, DSDP. Geochim. Cosmochim.Acta, 40, 413-423.

Pflumio C., Boulegue, J. and Tiercelin, J.J., 1994. Hydrothermal activity in the Northern Tanganyika Rift, East Africa. Chem. Geol. 116, 85-109.

Plisnier P.-D., Chitamwebwa, D., Mwape, L., Tshibangu, K., Langenberg, V. and Coenen, E., 1999. Limnological annual cycle inferred from physical-chemical fluctuations at three stations of Lake Tanganyika. Hydrobiologia, 407, 45-58.

Ricardo, C.K., 1939. Report on the fish and fisheries of Lake Rukwa in Tanganyika Territory and the Bangweulu region in Northern Rhodesia. London, Crown Agents for the Colonies London, UK. $78 \mathrm{pp}$.

Rodhe, H., Mukolwe, E. and Söderlund, R., 1981. Chemical composition of precipitation in East Africa. Kenya J. Sci. Technol., 2, 3-11.

Scanlon, B. R., 2000. Uncertainties in estimating water fluxes and residence times using environmental tracers in an arid unsaturated zone. Water Resour. Res., 36, 395-409.

Scholz, C.A. and Rosendahl, B.R., 1988. Low Lake Stands in Lakes Malawi and Tanganyika, East Africa, Delineated with Multifold Seismic Data. Science, 240, 1645-1648.

Stoffers, P. and Hecky, R.E., 1978. Late Pleistocene-Holocene evolution of the Kivu-Tanganyika Basin. Special Publications of the International Association of Sedimentologists, 2, 43-55.

Street-Perrott, F.A. and Harrison, S.P., 1985. Lake levels and climate reconstruction. In: Paleoclimatic Analysis and Modelling. A.D. Hecht (Ed.) Wiley, New York, USA. 291340 .
Symoens, J.J., 1968. The mineral content of natural waters, hydrobiological survey of Lake Bangweulu- Luapula river basin. Cercle Hydrobiologique de Bruxelles, 2, 1-119.

Talling, J.F. and Talling, I.B., 1965. The chemical composition of African Lake Waters. Int. Revue Gesamten Hydrobiologie, 50, 421-463.

Vance, R.E. and Wolfe, S.A., 1996. Geological indicators of water resources in semi- arid environments: Southwestern interior of Canada. In: Geoindicators: Assessing rapid environmental changes in earth systems, A.R. Berger and W.J. Iams (Eds.). Balkema, Rotterdam, The Netherlands. 237-250.

Vandelannoote, A., Deelstra, H. and Ollevier, F., 1999. The inflow of the Rusizi River to Lake Tanganyika. Hydrobiologia, 407, $65-73$.

Van Meel, L.I.J., 1987. Contribution à la limnologie de quatre grands lacs du Zaïre oriental: Tanganyika, Kivu, Mobutu Sese Seko (ex Albert), Idi Amin Dada (ex Edouard). Les paramètres chimiques. Fascicule A: Le Lac Tanganyika 1. Bruxelles, Institut Royal des Sciences Naturelles de Belgique.

Verburg, P., Hecky, R.E. and Kling, H., 2003. Ecological Consequences of a Century of Warming in Lake Tanganyika. Science, 301, 505-507.

Verschuren, D., Laird, K.R. and Cumming, B.F., 2000. Rainfall and drought in equatorial East Africa during the past 1100 years. Nature, 403, 410-414.

Vollmer, M. K., Weiss, R. F. and Bootsma, H. A., 2002. Ventilation of Lake Malawi/Nyasa. In: The East African Great Lakes: Limnology, Paleolimnology and Biodiversity, E. O. Odada and D.O.Olago (Eds.) Advances in Global Change Research, Kluwer, Dordrecht, The Netherlands. 209-233.

Yuretich, R.F. and Cerling, T.E., 1983. Hydrogeochemistry of Lake Turkana, Kenya: mass balance and mineral reactions in an alkaline lake. Geochim. Cosmochim.Acta, 47, 1099-1109. 